\title{
THE EVOLUTION OF THE ROLE OF FORMS OF MARKETING COMMUNICATION IN INFLUENCING CONSUMERS' SHOPPING BEHAVIOR (BASED ON SURVEYS IN 1995-2018)
}

\author{
EWOLUCJA ROLI FORM KOMUNIKACJI MARKETINGOWEJ \\ W ODDZIAŁYWANIU NA ZACHOWANIA ZAKUPOWE KONSUMENTÓW \\ NA PODSTAWIE WYNIKÓW BADAŃ ANKIETOWYCH W LATACH 1995-2018
}

\section{Krystyna Mazurek-Łopacińska, Professor}

The Wroclaw University of Economics and Business

53-345 Wroclaw, ul. Komandorska 118/120, bud. B, Poland

krystyna.m.lopacinska @gmail.com. ORCID 0000-0002-0034-8344

DOl: 10.2478/minib-2020-0030

\section{ABSTRACT}

The purpose of the article is to present the extent to which consumers use modern and traditional forms of marketing communication about the market offer, depending on the characteristics of these consumers, as well as to recognize the attitudes and market behavior of consumers under the influence these forms of communication, with particular emphasis on online advertising and social media. The basis of the analyzes are the results of the own, nationwide, surveys carried out in 1995, 2001 and 2017/2018. The importance of online information sources in influencing consumer behavior has grown dynamically, but the role of reference groups as a source of information on offers is still relatively large. Despite the increase in critical attitudes towards advertising, it does not significantly reduce its effectiveness in influencing consumers, although the mechanism of this influence is changing, as the strength of the behavioral component of the attitudes studied, is greater compared to the emotional component. Moreover, according to the criterion of age and education, there are significant differences in attitudes and the use of online sources of information between consumer groups, but these differences tend to decrease due to the growing rate of internet penetration. The generation Z's susceptibility to advertising is relatively the greatest, not only in relation to ads broadcasted on the web, but also offline ads. Consumers from this generation are also more likely to engage in various types of social media activity in shaping the market offer. 


\section{ABSTRAKT}

Celem artykułu jest przedstawienie zachodzących w długim okresie zmian w korzystaniu z tradycyjnych i nowoczesnych form komunikacji marketingowej oraz różnic pod tym względem między podstawowymi grupami konsumentów w zależności od cech tych konsumentów, a także rozpoznanie postaw i zachowań rynkowych konsumentów pod wpływem tych form komunikacji ze szczególnym uwzględnieniem reklamy internetowej oraz mediów społecznościowych. Podstawą analiz są wyniki własnych ogólnopolskich badań ankietowych przeprowadzonych w latach 1995, 2001 i 2017-2018. Z badań wynika, iz wzrostowi znaczenia internetowych form komunikacji w odziaływaniu na zachowania konsumentów towarzyszy wciąż stosunkowo duża rola grup odniesienia jako źródła informacji o ofercie. Zwiększa się również liczba krytycznych postaw wobec reklamy, ale nie zmniejsza się w sposób zasadniczy jej skuteczność w oddziaływaniu na konsumentów. Natomiast zmienia się mechanizm oddziaływania reklamy na konsumentów, gdyż rośnie siła składnika behawioralnego badanych postaw w porównaniu ze składnikiem emocjonalnym. Stosunkowo duże są różnice w postawach oraz w korzystaniu z internetowych form komunikacji między grupami konsumentów według kryterium wieku i wykształcenia, ale różnice te mają tendencję do zmniejszania się z uwagi na rosnący wskaźnik penetracji internetu. Relatywnie największa jest podatność pokolenia Z na reklamę — nie tylko w odniesieniu do reklam emitowanych w sieci, ale także reklam offline. Konsumenci z tego pokolenia częściej też podejmują różne rodzaje aktywności w mediach społecznościowych w ksztaltowaniu oferty rynkowej.

Słowa kluczowe: komunikacja marketingowa, konsument, zachowania zakupowe, reklama, media społecznościowe

JEL: M31, M37, M39

\section{Introduction}

The dynamic development of the digital economy in the modern world creates new conditions for the functioning of all market entities, including consumers, for whom it is particularly important to reduce the disproportion in relation to economic entities in terms of access to the market information. Consumers nowadays use many different sources of information about the market offer, which creates the possibility of taking more rational purchasing decisions.

The aim of the article is to present the changes taking place over time in terms of the use of modern and traditional forms of marketing communication and the differences between the primary groups of consumers in this respect depending on the characteristics of these 
consumers, such as: gender, age, education, source of income, place of residence (city - rural), as well as recognition of the attitudes and market behavior of consumers under the influence of the researched forms of marketing communication, in particular under the influence of various forms of advertising and social media.

The effectiveness of these forms in influencing the customers, and as a result in achieving the company's goals, depends on how they are perceived by consumers and how they influence their purchasing decisions.

Research conducted on various markets shows the increasing influence of online forms of marketing communication, mainly advertising and social media. The research emphasizes the importance of the informational value of Internet advertisements, which turns out to be greater than the hedonistic values (Taghipoorreyneh and De Run, 2016).

The impact of Internet advertisement, similarly as that of the TV ad is revealed mainly at the stage of shaping of the awareness, stimulating interest in the product and conviction to buy (Sama, 2019).

Research carried out by Malthous, Calder and other researchers shows that consumers' attitudes towards advertising are the result of their involvement in the use of a given advertising medium, i.e. a magazine, TV program or website (Malthouse, Calder, and Tamhane, 2007; Malthouse and Schaedel, 2009; Calder, Isaac, and Malthouse, 2016). Consumers prefering a given medium also have a more favorable attitude towards the advertising messages published in it. The Internet advertising, contrary to the TV advertisements has a more effective impact on generation $\mathrm{Y}$ than on $\mathrm{X}$ (Cheben, 2014). The research on the Polish market shows that the level of acceptance of advertising messages in 2014 was higher in traditional media than in the new media (Witczak, 2018). However, the growing expansion and popularity of online advertising strengthen the trend of using these ads by consumers and the increase in advertising spending in internet.

Despite the growing expenditure on this form of advertising, the relatively highest intensity in the world of using ad-blocking programs by Polish Internet users is also observed, which confirms the negative attitudes towards advertisement on the Internet, which is assessed as too intense, using manipulation techniques and violating privacy (Szubra and Trojanowski, 2018). A threat to the internet advertising is also posed by the 
divulged negative attitudes of mobile device users towards ads appearing in them (Bajdak, 2017). It does not change the fact that Internet advertising has become an important source of information about the offer for consumers and it more and more influences their buying.

At the same time, the important role of social media in shaping of the purchase decision is indicated, as they allow users to get acquainted with the reviews, opinions and comments of other people who previously bought the product. This information consists of the so-called "Zero moment of truth", i.e. the moment of making a purchase decision by verifying other sources of information and messages about the product, especially advertising (Lecinski, 2011; Parzonko, 2015). Forecasts show that social media and online video will maintain the highest growth rate compared to other advertising channels, which will average $16.6 \%$ and $13.8 \%$ annually in 2019-2022, mainly due to the constant increase in the use of mobile devices (Socialpress, 2020). The continuous development of the use of social networking sites also shows changes in user preferences towards broadcasts such as image or video, hence the growing popularity of such sites as Snapchat, Instagram, Periscope, and YouTube (Bartosik-Purgat, 2016). Research shows that in social media it is the context itself (i.e. the Platform), not the content of an advertisement, that is the key determinant of its effectiveness (Calder, Isaac, and Malthouse, 2016). This is an important premise of shaping of the profile of social networking sites in such a way as to stimulate the interest of clearly defined segments of users.

The analysis of social media use patterns by young consumers shows an increase in the importance of content, brand association and the role of the brand-centered community among those most willing to use social media, and at the same time a decline in the role of typically material factors in favor of content and information among the most skeptical people (Gasior, 2016).

It justifies examining the problem of the informational role of these media, as well as internet advertising.

\section{Research methodology}

In view of the increase in the share of online forms of communication about the offer, the focus was put just on these forms, i.e. mainly on online 
advertising and the social media. Traditional forms of communication were considered to a lesser extent, i.e. information from sellers, shop advertisements, press releases, press advertisements, radio and TV advertisements, as well as recommendations of relatives and friends and own experiences.

The basis for the analysis are the results of a long-term survey conducted by the author, i.e. at the beginning of the system changes in 1995 (as part of the KBN grant "Changes in consumer behavior in the conditions of transformation of the Polish economy") on a population of 1,004 consumers, then in 2001 on the population of 1,079 respondents and in the period $2017 / 2018$ on the population of 1,328 people. Research on the role of online advertising and social media focused mainly on $2017 / 2018$ due to significant differences in the level of development and use of the Internet in the three analyzed periods. The research was always of a nationwide character and was conducted in the following voivodeships: Low Silesian, Lubelskie Voivodeship, Lodz Province, Lesser Poland Voivodeship, Mazovian Voivodeship, Pomeranian Voivodeship, Podkarpackie Province, Silesian Voivodeship, the Greater Poland Voivodeship, and West Pomeranian Voivodeship. The percentage share of the questionnaire interviews conducted in each voivodeship corresponded to the share of the voivodeship population in the nationwide population. The samples used are comparable according to the basic criteria, ie age, sex, education, place of residence, city-village, main source of income. The quota sampling method was used, selecting respondents from the above-mentioned layers. The questionnaires were distributed via interviewers.

In each of the three mentioned periods, the same research tool was used in the form of a questionnaire, which made it possible to directly compare the obtained results of the research. The survey questionnaire included questions about the behavior of consumers in the market and their reaction to the marketing activities of enterprises in various marketing areas, including activities in terms of communication with customers. 


\section{Traditional and modern sources of information about the market offer in the shopping behavior of consumers}

The set of sources of information about goods and services offered on the market presented in Figure 1, in 2017/2018 indicated certain differences between consumers in the use of traditional and modern forms of this information. Every fourth respondent obtained information from social media, and almost every third respondent from the on line advertising, on the other hand, the role of conventional forms of advertising decreased, as only every fifth respondent indicated TV advertising, shop advertising one in ten, and advertising and press releases was indicated by approx. $6 \%$ of respondents, and only $2 \%$ the radio.

Despite the development of new forms of obtaining market information by consumers, the importance of such traditional sources as information from relatives and friends, which was used by every second respondent in the analyzed period, is not diminishing. The high level of trust in these sources of information is confirmed by the annual research by Nielsen (2015), as well as the results of international research conducted by the Kantar agency, according to which the most, that is $78 \%$ of respondents in 2018 declared confidence in market information obtained from family and friends (Étude, 2019). Moreover, the author's research shows that every third respondent declared that he was guided in his market choices by his own experience. Obviously, the role of own experiences is greater among the elderly, but the importance of recommendations from the reference groups does not differ across age groups. However, age significantly differentiates the use of social networking sites and internet advertising, which is much greater in younger age groups, and older respondents relatively more often declared obtaining information from TV advertisements, in-store advertising or directly from sellers. These traditional forms of advertising were also more often indicated as sources of information by people with primary and basic vocational education, while respondents with secondary and higher education are distinguished by more frequent use of information obtained from modern, that is electronic communication channels. 
The dominant share of information from relatives and friends was most visible in small towns up to 20,000 residents, who, compared to inhabitants of other towns, were also distinguished by the highest use of TV and instore advertisements, which results from a rather traditional model of consumer behavior.

The place of residence also significantly influences the scope of using one's own experience in obtaining information about the offer. It turns out that this source was relatively most often used by respondents living in large cities, i.e. over 200 thousand residents (37\%) and cities of 100-200 thousand residents (34\%), which can be explained by greater opportunities of gaining these experiences by them, compared to e.g. rural population or people living in small towns up to 20 thousand residents.

The large expansion of online advertising effectively affects the behavior of consumers searching for the information about the offer. Today, this source is used by all age groups, although obviously the most, because two or even three times more often, younger age groups, i.e. 18-25, 25-35 and 35-39 years old (Figure 1). More educated people also stand out, but mainly with secondary education, who are even ahead of people with higher education in this respect. People with primary education are in third place in the use of online advertising, and those with basic vocational education are the next, and although the distance to people from the previous groups is significant, it tends to level out due to the increasing Internet penetration rate.

It is also worth pointing to the differences in the use of online advertising depending on the source of income of the respondents. Their role is relatively the greatest in the group of freelancers, as well as those running their own business. The indicators for blue-collar workers are also at a similar level, although the direction of searching for information on the Internet is certainly different among them. Moreover, it turns out that the lack of professional activity (using the unemployment benefit or benefit from pensions or old-age pensions) does not exclude the use of online advertising, but only significantly reduces it, as it is evidenced by two and three times lower percentages of respondents declaring obtaining information about the offer from online advertising . 


\section{Figure 1. Where do You primarily obtain information about the product and service offer from}

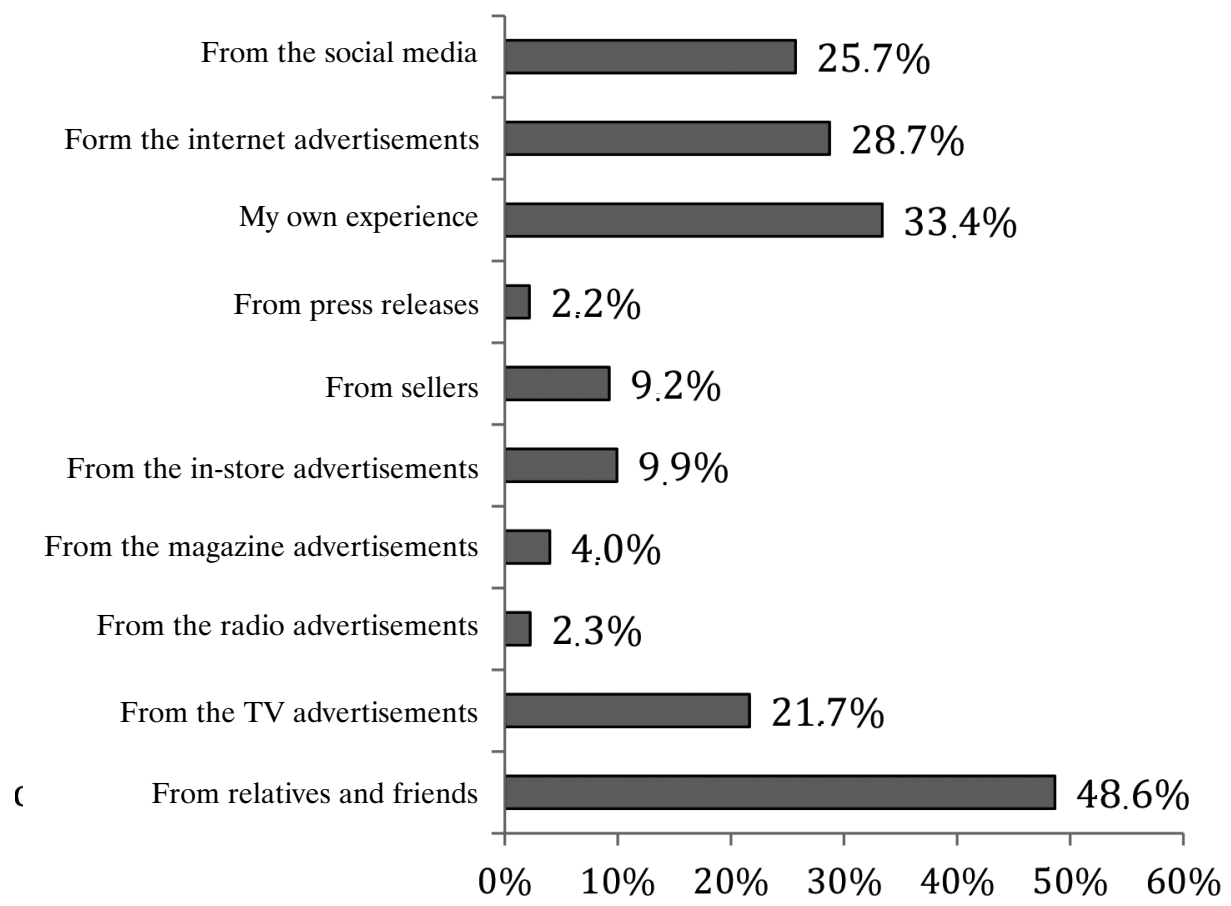

Source: own elaboration on the basis of the survey research.

At this point, it should be emphasized that Internet advertising is the most effective in shaping of the purchase decision of the most consumer goods surveyed, except for food, buying of which is still most encouraged by TV advertisement. Of the many consumer products, online advertising has the greatest impact on the purchase of clothing and footwear, cosmetics and books, but its effectiveness is also increasing in relation to other products.

In the age of the Internet, the role of social media in acquiring market information is competitive to various forms of advertising, which was indicated by $25.7 \%$ of respondents. 
When analyzing the sources of information about the offer used by consumers, it is necessary to point to the still quite high share of television advertising, indicated by an average of every fifth respondent, and among people over 60 and 40-49 years old, even every fourth declared that they used this source of information about the offer (Table 1). In this respect, inhabitants of small towns up to 20,000 also stood out (28.8\%), as well as retirees and pensioners and people using a farmstead (27\%).

The role of store advertisements and sellers as a source of information about the market offer is much smaller, as they were used on average by every tenth respondent, but in older age groups from 15 to $17 \%$, it was similar among people with primary and vocational education, as well as people living in cities and towns up to 20 thousand residents. The information provided by sellers was most often used by older people, especially 50-59 years old (19.2\%), as well as retirees and pensioners, farmers and those living on unemployment benefit. They were also more often rural inhabitants who are more susceptible to the influence of personal forms of communication.

Table 1. Sources of information about the offer of goods and services used by consumers representing various age groups (percentage of respondents)

\begin{tabular}{l|r|r|r|r|r|r}
\hline \multirow{2}{*}{\multicolumn{1}{c|}{ Sources of information }} & \multicolumn{7}{c}{ Age group } \\
\cline { 2 - 7 } & $\mathbf{1 8 - 2 4}$ & $\mathbf{2 5 - 2 9}$ & $\mathbf{3 0 - 3 9}$ & $\mathbf{4 0 - 4 9}$ & $\mathbf{5 0 - 5 9}$ & $\mathbf{6 0}$ and more \\
\hline Relatives and friends & 50.1 & 48.9 & 46.4 & 47.2 & 46.2 & 47.4 \\
TV ads & 20.5 & 19.6 & 23.2 & 24.5 & 21.2 & 25.6 \\
Radio ads & 1.4 & 1.6 & 4.2 & 3.1 & 3.8 & 2.6 \\
Magazine advertisements & 1.9 & 4.9 & 6.5 & 5.0 & 7.7 & 6.4 \\
Store advertisements & 9.8 & 8.7 & 6.5 & 8.2 & 16.3 & 15.4 \\
Sellers & 6.8 & 6.5 & 8.3 & 13.2 & 19.2 & 16.7 \\
Press releases & 1.7 & 2.2 & 3.0 & 2.5 & 1.0 & 5.1 \\
Own experience & 30.6 & 29.3 & 30.4 & 39.6 & 41.3 & 37.2 \\
Internet ads & 35.0 & 34.2 & 32.1 & 13.2 & 13.5 & 9.0 \\
Social media & 32.3 & 30.4 & 18.5 & 19.5 & 8.7 & 12.8 \\
\hline
\end{tabular}

Source: own elaboration on the basis of the survey research. 
Knowledge of diversification of the sources of information used by consumers has a high application value, providing companies with the guidance necessary to shape effective communication strategies and message concepts.

\section{Changes in consumers' attitudes towards advertising across age groups}

Observing the reaction of Polish consumers to various forms of communication is the domain of sociological, psychological, cultural and economic research, the results of which also expand the knowledge of managers striving to increase the effectiveness of influencing the market and achieve competitive advantage. Due to the dominance of advertising in the media space, it is necessary to constantly monitor consumer attitudes and behavior towards its ever newer forms, which also facilitates the assessment of the processes of adaptation of Polish consumers to the conditions of the market economy.

In the first years of the economic and political transformation, positive attitudes of consumers towards advertising dominated, mainly in the cognitive and behavioral layer. Consumers indicated their informative value, stimulating curiosity and encouraging to act, although in the emotional layer, critical opinions prevailed, as it was more often emphasized that advertisements irritate and unnerve than relax and entertain.

The author's research showed that in 1995, six years after the systemic transformation, $40 \%$ of consumers had a positive attitude towards advertising, the same number had a neutral attitude, and one in five declared a negative attitude. The following years saw a significant decline in positive attitudes (by 20 percentage points in 2001) and an increase in negative attitudes. This is confirmed by CBOS research carried out in 1992-2011. According to respondents, instead of informing, advertisements disinform (67\%) and bore recipients (80\%), and in addition, they discourage them from buying (73\%) and irritate (81\%) (CBOS, 2011 ).

Changes in attitudes towards advertising are particularly visible in the cross-section of the basic generations of consumers, as it is expressed in the 
results of the 2018 survey conducted by IRCenter (Wójcicka, 2018) regarding both the emotional component of an attitude and its behavioral component. First of all, they confirm big differences between the generations of consumers in terms of preferred forms of advertising, as the Baby Boomers and Gen X prefer offline advertising (leaflets, magazine ads, TV advertising spots, outdoor and radio advertising) in the environment in which they grew up in, unlike the younger generations, especially the $\mathrm{Z}$ generation, but also Millennials, who prefer digital forms of advertising, especially advertising on Facebook, events and advertisements on Instagram. At the same time, a very interesting regularity was observed showing the greater strength of the behavioral component of the researched attitudes in comparison with the emotional component, as relatively more respondents declare the influence of the researched forms of advertising on purchasing decisions than them being fond of these forms. It proves the effectiveness of advertising in influencing consumers, both offline and digital. In addition, younger generations of consumers are much more susceptible to advertising, and this applies not only to offline ads, but also to advertisements broadcasted on the web. Thus, events are important in shaping of purchasing decisions for $52 \%$ of Generation $\mathrm{Z}$ representatives, $47 \%$ of these respondents show sensitivity to Facebook ads, and $49 \%$ of people of this generation are convinced by TV and outdoor advertisements to buy. It also proves the still strong position of offline advertising in shaping of the consumer behavior.

The research conducted by the author shows that advertising is best received by young people aged 18-29. On the other hand, the positive impact of education and the nature of employment on attitudes towards advertising is diminishing. After the period of high acceptance of advertising by people running their own business or performing medium and high-level work, the growing criticism of these people towards advertising is progressing, which reduces the existing differences between consumer groups.

\section{Behavioural effects of various forms of advertising}

The degree of influence of advertising on consumers' market decisions is evidenced by their purchases made under the influence of advertising. It 
turns out that after a period of an increase in the number of buyers from $32.3 \%$ in 1995 to $38 \%$ in 2001 , there was a decrease in the number of people declaring that they had bought a product under the influence of advertising to $32.1 \%$ in $2017 / 2018$ (Table 2).

\section{Table 2. Number of consumers who recently (1/2 year) bought a product (service) under the influence of advertising (percentage of consumers)}

\begin{tabular}{|c|c|c|c|c|c|c|c|}
\hline \multirow{2}{*}{ Year } & \multicolumn{7}{|c|}{ Age (in years) } \\
\hline & $18-24$ & 25-29 & 30-39 & $40-49$ & $50-59$ & 60 and more & overall \\
\hline 1995 & 44.5 & 42.6 & 28.7 & 31.7 & 22.1 & 24.6 & 32.3 \\
\hline 2001 & 52.1 & 42.3 & 40.1 & 35.3 & 26.4 & 22.9 & 38.1 \\
\hline \multirow[t]{3}{*}{$2017 / 2018$} & 35.8 & 37.9 & 29.0 & 23.1 & 24.7 & 26.0 & 32.1 \\
\hline & \multicolumn{7}{|c|}{ Level of education } \\
\hline & \multicolumn{2}{|c|}{ primary } & \multicolumn{2}{|c|}{ secondary vocational } & \multicolumn{2}{|c|}{ medium } & high \\
\hline 1995 & \multicolumn{2}{|c|}{20.1} & \multicolumn{2}{|c|}{22.4} & \multicolumn{2}{|r|}{39.7} & 38.5 \\
\hline 2001 & \multicolumn{2}{|c|}{18.5} & \multicolumn{2}{|c|}{30.5} & \multicolumn{2}{|r|}{40.7} & 45.4 \\
\hline $2017 / 2018$ & \multicolumn{2}{|c|}{26.1} & \multicolumn{2}{|c|}{22.5} & \multicolumn{2}{|r|}{34.5} & 31.0 \\
\hline
\end{tabular}

Source: own elaboration on the basis of survey research.

As the conducted research shows, the impact of advertising on purchasing decisions varies depending on such consumer characteristics as: age and education level. The younger and better educated the consumer is, the more willingly he is to make purchases under the influence of advertising. Among the respondents aged 18-24, as well as among those who have higher education, in 2001 almost one in two made a purchase under its influence, and among the oldest and less educated respondents only one in five. In $2017 / 2018$, the differences in this respect between better and less educated respondents decreased significantly, but the regularities observed above were maintained.

Consumers show different sensitivity to advertising of particular goods, which along with the varying intensity of advertising activities as well, means that advertisement has a different impact on the purchase of these goods. The declarations of respondents who bought a product under the 
influence of advertisement in 2017/2018 show that it had the strongest impact on decisions to purchase food, clothing and footwear, various types of services and cosmetics. The advertising influenced the purchases of books, various services, computers, smartphones and cleaning products to a slightly lesser extent. Whereas, its relatively smallest impact on the purchase decisions of tourist equipment, household appliances and audio/video devices, as well as jewellery. It must be admitted that the purchases of the latter group of products is shaped by a much more complex set of factors, among which advertisement does not play the most important role. In the set of criteria for selecting these products, price is particularly important, therefore advertisement plays only the role of a factor supporting market decisions.

As it has already been emphasized, among the various forms of advertising, it is no longer the TV advertisement that has the strongest impact on consumers, but Internet advertising, as every third respondent made a purchase under its influence, and the effectiveness of TV advertising came second (20.6\% of respondents). Internet advertising influenced the purchases mainly of: clothing and footwear, cosmetics and books, as well as computers and smartphones. Meanwhile, TV advertising turned out to be the most effective in persuading people to buy food products, as indicated by every third respondent, and next, due to the $12-14 \%$ of the respondents purchasing under its influence were cosmetics and cleaning products.

An expression of the influence of new technologies on the purchasing process of a modern consumer is the use of mobile technology to a greater extent in making purchases, declared, according to the author's own research, by $45.6 \%$ of respondents, although the vast majority, i.e. $87.4 \%$, used desktop computers, because thanks to large screens they create better opportunities for detailed familiarization with a given product. The role of tablets is much smaller, as it was indicated by $16.6 \%$ of respondents, and other devices such as a console or a smart watch are still of marginal importance.

The use of smartphones in the purchase process was the highest in the group of buyers aged 18-25 and decreased with the age of the buyer from $61.6 \%$ in the youngest group, $48.4 \%$ in the $25-29$ group to $3.8 \%$ among consumers 60 years and more (Table 3 ). 


\section{Table 3. Devices used by consumers in the purchase process (percentage of respondents)}

\begin{tabular}{l|r|r|r|r|r|c}
\hline \multirow{2}{*}{\multicolumn{1}{c|}{ Devices }} & \multicolumn{7}{c}{ Age (in years) } \\
\cline { 2 - 7 } & $\mathbf{1 8 - 2 4}$ & $\mathbf{2 5 - 2 9}$ & $\mathbf{3 0 - 3 9}$ & $\mathbf{4 0 - 4 9}$ & $\mathbf{5 0 - 5 9}$ & $\mathbf{6 0}$ and more \\
\hline Personal computer & 91.7 & 94.6 & 90.5 & 84.9 & 75.0 & 51.3 \\
Smartphone & 61.6 & 48.4 & 44.6 & 25.2 & 6.7 & 3.8 \\
TV set & 0.6 & 1.6 & 1.8 & 0.0 & 1.9 & 3.8 \\
Tablet & 18.0 & 15.8 & 23.2 & 18.9 & 4.8 & 5.1 \\
Console & 0.9 & 2.2 & 0.6 & 0.0 & 0.0 & 1.3 \\
Smartwatch & 0.6 & 0.0 & 0.6 & 1.3 & 0.0 & 1.3 \\
\hline
\end{tabular}

Source: own elaboration on the basis of survey research.

There is also a clear influence of the level of education and the main source of income on the use of modern devices in shopping, which is a derivative of the style of shopping, especially e-commerce. They are mostly used by representatives of free professions and self-employed persons, taking into account the level of education of persons with secondary and higher education.

\section{The importance of social media in purchasing behavior}

Due to the growing influence of social media in acquiring market information, it was examined which of them are the most effective in shaping of the purchasing decisions. Social networking sites such as Facebook, Instagram (39.2\% of respondents) were mentioned in the first place, followed by internet forums (29.1\%) and price comparison websites, e.g. Opineo.pl (20.6\%). Blogs (culinary, fashion, etc.) indicated by $17.4 \%$ of respondents or internet auctions (14.8\%) are slightly less important, and the smallest role, indicated by a small percentage of respondents, is played by professional communities (e.g. Linkedln, Goldenline) and citizen journalism services.

The role of social media in influencing purchasing processes depends primarily on the age of consumers. Younger consumers, i.e. 18-24 and 
25-29 years old, prefer social networks (Facebook, Instagram, etc.), as it was indicated by every second respondent, while in older age groups, especially 30-39 and 40-49 years old, a much greater role as a source of information was played by Internet forums and price comparison websites, which were indicated even by $38 \%$ of people aged $30-39$ and 27 to $30 \%$ in the group of respondents 40-49 years old.

Moreover, there is a rising popularity of blogs as a source of information about the market offer, which are used for this purpose more often by the youngest consumers, i.e. every fourth aged 18-24, and almost every fifth aged 25-29, but this source was also pointed out by older people, even over 60 years old $(7.7 \%$ of the respondents). Women, compared to men, more often obtained information about the offer from social networks, opinion and recommendation websites, such as Opineo.pl, as well as blogs, while men stood out in terms of using the internet forums. However, the degree of use of price comparison websites is very similar between the sexes, as it was indicated by every fourth respondent.

Small percentages of respondents indicated such sources of information about the offer as portals for professionals, e.g. Linkedln or Goldenline, as well as citizen journalism services, which were more often used by men, as well as self-employed persons. Interestingly, they were used to a similar extent both by residents of large and small towns.

The importance of social media in influencing purchasing processes is clearly differentiated depending on the education of consumers. Popular social networks such as Facebook and Instagram play the greatest role in the purchasing behavior of people with secondary education, which was declared by almost every second respondent, among people with primary education $38 \%$, and the least, because $21 \%$, among people with basic vocational education. Social networks also have a relatively large share in shaping of the purchasing behavior of people with higher education, as it was emphasized by $34 \%$ of these respondents, and moreover, this group of respondents stood out in terms of using such types of social media in purchasing processes as: internet forums (31\%) price comparison websites, eg Ceneo (31\%) and opinion and recommendation websites, including: Opineo.pl (22\%). These media also play a relatively large role in influencing the purchasing processes of people with secondary education, which was emphasized by approx. 21-27\% of these respondents. 
Conducting research among young consumers on various markets confirms the growing role of social media in shaping of the market consumer behavior. A study conducted by GFK on Facebook in 2017 on the market of cosmetic products in Great Britain, France, Germany and the United Arab Emirates shows that $72 \%$ of consumers of cosmetics made purchases under the influence of information on the Internet (L'influence..., 2019), and almost $40 \%$ of consumers claimed they would more likely buy a brand that they see on Facebook or Instagram. This is confirmed by research on local markets, e.g. carried out in Poznań on the clothing market in 2017-2018 among people aged 16-26 (Stachowiak-Krzyżan, 2019). The research shows that the content published by companies in social media encourages, first of all, to get acquainted with the company's online store offer, which was declared by $78 \%$ of respondents, and then to consider buying a given brand's product $(67 \%)$ and making such a purchase (57\%). Moreover, to a similar extent it stimulated consumers to visit the stationary stores, and additional advantage for the company is in recommending the purchased clothing brand to relatives and friends, which is declared by $41 \%$ of respondents. A similar percentage, $44 \%$, indicated that in their purchasing decisions they follow the promotional offers placed on social media (Szulzyk-Cieplak, Puchtel, and Płecha, 2017). Social media is a source of inspiration for consumers, as well as a trust-shaping factor, as the consumer has a chance to get acquainted with the opinions of both influential people and anonymous, average users. Deloitt's research shows that for $27 \%$ of Generation $\mathrm{Z}$ representatives, it is the recommendations of friends in social media that are of key importance in making decisions about the purchase of goods and services (Digital Democracy Survey, 2017). The quality of the visualization of the advertised products also plays an important role. Therefore, the presence of the company on social media has a significant impact on shopping behavior.

\section{Forms of consumer activity in social media}

Contemporary consumers do not stop at only obtaining information from social networks and using it to communicate with others or making purchases, but they also undertake various types of activity in shaping of 
the market offer. The author's research shows that, on average, every fifth of them declared that they willingly evaluate and give opinions on products on the internet forums and in other social media. This form of activity was more often undertaken by younger, i.e. $18-24$ year old consumers $(24.2 \%$ of the respondents), and among consumers 25-29 years old even every third person declared such activity. Whereas older consumers very rarely evaluate and give their opinion about products on the web, as it was indicated by only $3.9 \%$ of respondents aged 50-59 (Table 4).

Moreover, men slightly more often than women engage in such activities, and taking into account the place of residence, the residents of medium and large cities, although the cities with 50-100 thousand residents stand out in this respect, where $32 \%$ of respondents gave their opinion on products and posted comments in social media, while only $17.7 \%$ of the rural population did so. Representatives of free-lance professions are also distinguished, as every third of them declared undertaking such a form of activity, and among retirees and pensioners only $7.7 \%$.

\section{Table 4. Forms of online activity undertaken by consumers of various age groups in cooperation with a company (percentage of respondents)}

\begin{tabular}{l|r|r|r|r|r|r}
\hline \multicolumn{1}{c}{ Forms of activity } & \multicolumn{7}{c}{ Age (in years) } \\
\cline { 2 - 7 } & $\mathbf{1 8 - 2 4}$ & $\mathbf{2 5 - 2 9}$ & $\mathbf{3 0 - 3 9}$ & $\mathbf{4 0 - 4 9}$ & $\mathbf{5 0 - 5 9}$ & $\mathbf{6 0}$ and more \\
\hline I willingly evaluate and give my opinion & & & & & & \\
$\quad$ on products on forums and stores' websites & 24.2 & 29.1 & 19.2 & 14.5 & 3.9 & 7.8 \\
I submit ideas to make the offer more attractive & 3.3 & 2.2 & 3.0 & 0.0 & 1.0 & 1.3 \\
I present to the company new product designs & 2.9 & 4.4 & 2.4 & 0.0 & 0.0 & 3.9 \\
I don't take up such activities & 69.6 & 64.3 & 75.4 & 85.5 & 95.1 & 87.0 \\
\hline
\end{tabular}

Source: own elaboration on the basis of survey research.

When evaluating the forms of activity undertaken by Internet users aimed at shaping of the market offer, it should be emphasized that a very small percentage of respondents (approx. 3\% on average) declared greater involvement in this respect, consisting in submitting ideas to make the offer more attractive as a part of special campaigns organized by companies. Even fewer Internet users offered new product concepts and designs to companies on their own initiative. 


\section{Conclusions}

The conditions of the contemporary market, and especially the influence of new information and communication technologies, are changing the purchasing behavior of consumers, who increasingly make use of the new opportunities and facilities offered to them in the purchasing process. Despite the increasing significance of online forms of communication, the role of reference groups as a source of information about the offer is still relatively large, which is confirmed by the results of author's original research conducted over a long period, i.e. 1995, 2001, 2017/2018. This is also confirmed by the results of international research conducted by the Kantar research agency on the five largest consumer markets (Brazil, China, France, the USA and Great Britain), which show that every second consumer obtains information about brands from family and friends, as it is the source of information with the highest level of trust. The Trust Index was 78\% in 2018 with 33\% for advertising and $46 \%$ for social media (Étude, 2019). Explaining the causes of this phenomenon requires in-depth research results through the recognition of psychological and sociological mechanisms forming consumer behavior. This sets the direction for applying qualitative motivational research.

The presented rise in critical attitudes towards advertising does not significantly reduce its effectiveness in influencing consumers, but the role of particular forms of advertising changes to the benefit of Internet advertising and social media. This is confirmed by the changes of attitudes towards various forms of advertising analyzed across the basic generations of consumers, which show the greatest susceptibility of Generation $\mathrm{Z}$ to advertising, not only in relation to advertisements broadcasted on the Internet, but also offline ads. It proves the still strong position of offline advertising in shaping of the consumer behavior. At the same time, the role of social media is increasing, not only of social networks (Facebook, Instagram), but also of online forums, price comparison websites, and opinion and recommendation websites. There is also a rise in popularity of blogs as a source of information about the market offer.

It can be concluded that the large diversification of the role of social media in shaping of purchases depending on the age, education of consumers, main source of income and place of residence results mainly from the different pace of the process of adopting new technologies by Polish consumers. Consumers from younger age groups, as well as those living in 
medium and large cities, as well as representatives of freelance professions who are most familiar with these technologies, are also distinguished by their activity in forming of the market offer, evaluating and giving opinions on products, although the more advanced forms involving participation in the creation of new products are still rarely used. The greater involvement is shown by the participants of online communities centered around the brand, especially those interested in cooperating with the company the most. Investing by companies in social media platforms helps to trigger the engagement and creativity of platform users, which brings them satisfaction and, as a result it translates into the increase of sales. The demonstrated differences between groups of consumers in reactions to these stimuli expand the knowledge necessary to formulate structural and cause-effect regularities in consumer behavior. They can also constitute a premise for the differentiation by managers of communication messages used in the policy of communication with the market.

\section{References}

1. Bajdak, A. (2017). Wybrane uwarunkowania stosowania reklamy mobilnej w Polsce. Studia Ekonomiczne, 328, 61-69.

2. Bartosik-Purgat, M. (2016). Media społecznościowe na rynku międzynarodowym. Perspektywa indywidualnych użytkowników. Warszawa: Difin.

3. Calder, B. J., Isaac, M. S., \& Malthouse, E. C. (2016). How to capture consumer experiences: A context-specific approach to measuring engagement. Predicting consumer behavior across qualitatively different experiences. Journal of Advertising Research, 56(1), 39-52.

4. CBOS (2011). Nudza, drażnia, dezinformuja: Polacy o reklamach. (Komunikat Badań BS/16/2011). https://www.cbos.pl/SPISKOM.POL/2011/K_016_11.PDF

5. Cheben, J. (2014). Effectiveness of TV advertising when targeting generations $\mathrm{Y}$ and X. Proceedings of the 5th International Scientific Conference on Trade, International Business and Tourism. EKONÓM, University of Economics in Bratislava.

7. Digital Democracy Survey (2017). A multi - generational view of consumer technology, media, and telecom trends (Eleventh Edition). Retrieved from http://www.deloitte. com/us/digitalmediatrends

7. Étude (2019). Quand le ciblage excessif nuit a la publicité digitale. Retrieved from https://lareclame.fr/kantarmedia-dimension-publicitedigitale-217757

8. Etude Facebook IQ (2017). Comment les réseaux sociaux revolutionne notre raport a la beaute. Retrieved from http://www.marketers.lu

9. Gąsior, M. (2016). Wzorce korzystania z mediów społecznościowych a zaangażowanie młodych konsumentów w komunikację marketingową przedsiębiorstwa - analiza zmian w latach 2013-2015. Prace Naukowe Uniwersytetu Ekonomicznego we Wroctawiu, 459, 171-182. 
10. Kuchta-Nykiel, M. (2020). Social media w Polsce i na świecie - najnowsze dane. Socialpress. Retrieved March, 2020, from https://socialpress.pl/2020/02/social-media-wpolsce-i-na-swiecie-najnowsze-dane

11. L'influence des réseaux sociaux sur la consommation de produits de beauté (2019). Retrieved from https://www.agencedesmediassociaux.com/linfluence-reseaux-sociauxconsommation-de-produits-de-beaute

12. Lecinski, J. (2011). Winning the zero moment of truth. Retrieved from http://www.thinkwithgoogle.com

13. Malthouse, E. C. \& Schaedel, U. (2009). An experimental study of the relationship between online engagement and advertising effectiveness. Journal of Interactive Marketing, 23, 321-31.

14. Malthouse, E. C., Calder, B. J, \& Tamhane, A. (2007). The effects of media context experiences on advertising effectiveness. Journal of Advertising, 36(3), 7-18.

15. Nielsen (2015). Global trust in advertising report: Winning strategies for an evolving media landscape. Retrieved from https://www.nielsen.com/us/en/insights/report/2015/ global-trust-in-advertising-2015/

16. Parzonko, A. J. (2015). Wpływ mediów społecznościowych na zachowania konsumentów. Handel Wewnętrzny, 6(359), 122-131.

17. Sama, R. (2019). Impact of media advertisements on consumer behaviour. Journal of Creative Communication. https://journals.sagepub.com/doi/10.1177/0973258618822624

18. Stachowiak-Krzyżan, M. (2019). Wykorzystanie mediów społecznościowych przez młodych konsumentów w procesach zakupowych. Marketing Instytucji Naukowych i Badawczych, 31, 83-108.

19. Szubra, K. \& Trojanowski, M. (2018). Postawy konsumentów wobec reklam internetowych. Marketing i Rynek, (4), 521-538.

20. Szulżyk-Cieplak, J., Puchtel, A., \& Płecha, A. (2017). Media społecznościowe jako narzędzia reklamy internetowej. Edukacja - Technika - Informatyka, 8(2), 290-295.

21. Taghipoorreyneh, M. \& De Run, E. C. (2016). Online advertising: an investigation of factors affecting positive attitude among the Malays in Malaysia. Asian Journal of Business Research, 6(2), 70-80.

22. Witczak, O. (2018). Postawy i opinie konsumentów indywidualnych wobec reklamy w nowych i tradycyjnych mediach. Marketing i Rynek, (8), 830-838.

23. Wójcicka, O. (2018). Od Baby Boomers do pokolenia Z - co o reklamie sądza poszczególne generacje konsumentów. Nowy Marketing. Retrieved from https:/nowymarketing.pl/a/ 20343,od-baby-boomers-do-pokolenia-z-co-o-reklamie-sadza-poszczegolne-generacjekonsumentow 


\section{Krystyna Mazurek-Łopacińska, Professor, The Wroclaw University of Economics and Business, Poland}

- Professor of Economic Sciences, Head of the Marketing Research Department of The Wroclaw University of Economics and Business (since 1994), Deputy Rector for Didactics at the WUE (in the years 2002-2005) and Head of the Marketing Institute (2011-2016). She served Her internships at the University of Lille, International Business School in Marseilleand at the Paris-Evry University. One of the leading Polish specialists in the sphere of marketing research and economics of consumption, as well as consumer market behavior. Her scientific and research interests concern marketing strategies, customer orientation in the enterprise, intercultural marketing communication, marketing in the culture sphere. Her scientific achievements include over 300 published items (monographies, textbooks and articles), among them are Her books concerning the Consumer Behavior which were awarded with the Prizes of the Minister of Higher Education: „Purchasers' Behavior as the Basis of the Marketing Strategy", Wydawnictwo Uniwersytetu Ekonomicznego we Wroctawiu 1996 (Publishing House of the University of Economics in Wroctaw), and „Purchasers' Behavior and Its Marketing Consequences”, Polskie Wydawnictwo Ekonomiczne 2003 (Polish Economics Publishing House). She is an editor and co-author of 16 monographies i Scientific Works dedicated to the methodology issue and implementation of the marketing research, as well as textbooks, the last one - "Marketing Research. Methods, Techniques and Areas of Application in The Modern Market" was published in 2016 by Polskie Wydawnictwo Naukowe (Polish Scientific Publishing House). She is a co-author of the monography "Marketing in the Digital Technologies Era. Modern Conceptions and Challenges" published by PWN in 2018. A third-party examiner at the Nottingham Trent University (2007-2013) and the Chairwoman of the Accreditation Commission of the Foundation for the Promotion and Accreditation of Economic Education (2005-2016). She is a member of the Committee on Organizational and Management Sciences of the Polish Academy of Sciences (2015-2020). As a recognized expert she was a member of the Permanent Team of the National Science Centre (2012-2015). She also is a member of the Reseau des Pays du Groupe de Vysegrad Association. 